\title{
Board Composition, Structure, And Financial Performance: An Update
}

\author{
Kevin Bosner, (E-mail: kbosner@sjfc.edu), St. John Fisher College
}

\begin{abstract}
In 1998, a meta-analysis of over 60 empirical research studies concluded that there was no demonstrable evidence that either Board of Directors structure or the duality of CEO/Board Chairman roles significantly impacted corporate performance. This article looks at research done since that time, in light of Enron and other corporate scandals as well as the Sarbanes-Oxley Act of 2002 and the increasing diversity of corporate boards. Four additional studies, including follow-up work done by the authors of the 1998 meta-analysis, are compared and contrasted. In addition, the results of direct research on twenty Fortune 100 companies is presented. Finally, suggestions for future research in terms of both topic and methodology are provided, along with this author's learnings from the project.
\end{abstract}

\section{INTRODUCTION}

\section{Purpose Of The Article}

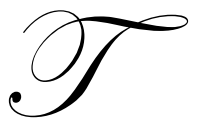

he question of the level and type of influence and impact which different forms of corporate governance have on organizational financial performance has a long but mixed history of writing, theory and research, in terms of both academic and empirical work. The essential argument boils down to a question of the strength and direction of the impact which a Board of Directors structure has on corporate performance. Various research findings can be brought out to support hypotheses that "insider-dominated" or "outsider-dominated" Boards have a positive effect, a negative effect... or no significant impact at all on corporate financial performance! A similar and related argument revolves around the impact, if any, of combining the roles of CEO and Chairman of the Board. Again, research has produced conflicting and inconsistent results.

One study (Dalton, Daily, Ellstrand and Johnson, 1998) took a meta-analytic approach to the question. (Note: This research and the paper that described it will be described here as "the Dalton study" for brevity's sake.) Through a review of 63 empirical studies the authors hoped to determine patterns of impact on corporate financial performance stemming from either board composition or CEO/Chair duality. This update takes a narrative view in describing four in-depth studies carried out on this same topic since 1998. One reason for choosing the narrative method as opposed to the meta-analytic approach is the comparatively small number of studies published since the Dalton study was done in 1998 .

\section{Reasons To Perform An Updated Review}

Why update this study at all? Because several events have occurred since 1998 which at least raise the question of whether more current findings would yield the same results. First, the many corporate scandals, the most infamous of which was the Enron debacle of 2001, have brought even more intense scrutiny than before to the whole subject of corporate governance, and specifically to the question of a Board of Director's responsibility and accountability for corporate results (Alsop, 2004). Second, the Sarbanes-Oxley Act of 2002 legislated a number of reforms to Board structure, to increase Director independence and impartiality and to improve the quality of audited financial information. (Giroux, 2004). Third, a new focus on diversity and inclusion has led several corporations to consciously increase the number of women and people of color on their Boards (Miller and Katz, 2002). Different types of people on the Board bring different perspectives, which may in turn bring about different results. 
This article reviews four studies published subsequent to the Dalton work, including an updated review of their own research performed by the authors of the 1998 Dalton study (Dalton, Daily, Certo \& Roengpitya, 2003). In addition, the Board structure, and the financial performance, of the thirty top Fortune 100 companies from 2003 to 2005 are directly analyzed. By comparing this newer information to the 1998 findings, the hope is that those earlier findings may be either supported or challenged. Additionally, future research areas, topics, and a possible change in methodology will be suggested.

\section{SUMMARY OF DALTON'S STUDY}

In the introduction to the 1998 Dalton work entitled, "Meta-Analytic Reviews of Board Composition, Leadership Structure, and Financial Performance," the authors stated that their goal was to "provide some rationale for an alternative perspective" (270) to two essentially opposing views about corporate governance, specifically how and whether Board of directors composition, and $\mathrm{CEO} /$ Chairperson duality, effect corporate financial performance.

The first of these views is based primarily on agency theory. Agency theory begins with the fact that many corporate managers are not owners but agents of owners, contracted to manage the company on their behalf. Since they are not directly owners but managers, and thus have less personal wealth at stake, their natural pursuit of selfinterest could result in them taking riskier, or even dishonest, actions, which could bring harm to the firm or its owners. (Jensen \& Meckling, 1976). Proponents of this view have long supported the idea of a Board of Directors dominated or at least strongly influenced by people not otherwise employed by the organization. They also argue for a separation of the functions of Chief Executive Officer and Board Chairperson. Conceptually, separating these functions, and increasing outside influence, should both monitor and moderate the natural self-promoting efforts of managers, and thereby protect the owners' (shareholders') wealth. In fact, moderating the risk of unethical or improper management behavior is one of the key arguments made by stockholder activists (Corporate Governance, 2005).

In contrast to agency theory stands another point of view, this one grounded in stewardship theory. Stewardship theory supports the concept that managers are essentially worthy of trust. The assumption in this case is that the managers of a corporation will apply their efforts and skills conscientiously to achieve profitability and earn returns for the shareholders. Clearly, this point of view would tend to favor a Board of Directors dominated, or at least more heavily influenced, by insiders, that is, members who are also employed by the corporation in addition to their Board duties. In addition, this school of thought points to the merits of having one person serve as both CEO and Board Chair. Examples of the benefits of this duality include a greater familiarity with the workings of the business itself, as well as the industry in which it operates. But essentially the argument comes down to whether and how much the degree of Board and/or CEO independence helps or hinders the corporation.

Proponents of either of these opposing theories can - and do - each quote several research studies to support their very different points of view. Dalton et al (1998) pointed out that, in addition to studies supporting both forms of corporate governance as having positive impact on performance, there are also studies that indicate no significant relationship between them. Dalton et al (1998) stated that there was very little consistency to be found in the research done up to the point of their article. (271)

As mentioned earlier, the Dalton study was a meta-analysis of 54 studies of board composition and 31 of leadership duality, a total of 63 discrete research instruments, since some studies considered both board composition and duality. In addition, they identified several moderating factors - including firm size, accounting-based vs. market-based performance measures, and proportion of inside, outside, affiliated, or independent members of the Board.

Based on their findings, Dalton et al reached the conclusions that:

board composition has virtually no effect on firm performance," (278); "that there is no relationship between board leadership structure and firm performance," (280); and that "there is no evidence of a moderating effect of particular 
operationalizations of board composition"(280), and neither firm size nor the type of performance measure used made any significant difference. (280)

\section{REASONS TO UPDATE THE RESEARCH}

At the conclusion of their article, Dalton et al suggested reasons that their study may have produced no significant connection between board composition, leadership and financial performance. They indicated that further research might not be fruitful, unless it focused on a more specific population, which they felt might help eliminate some of the moderating variables which admittedly colored their findings. They stated their concern that their approach could "fail to captue the subtleties" of relationships within the Board itself, that is in the committees and sub groupings which carry out many board functions. (284).

In addition to the authors' own suggestions, several events occurred since the publication of this article which argue for an updated look at this topic.

\section{Enron And Other Scandals Increased The Focus On Corporate Governance.}

Not long after the above article was published, the business world was shaken by a series of corporate scandals, the most infamous of which was the collapse of Enron Incorporated and the subsequent indictment, conviction and demise of Arthur Andersen, one of the nation's largest Public Accounting firms. Andersen had been the auditor for Enron as well as for several other companies including WorldCom and Sunbeam which were also tainted by accounting and reporting fraud. (Citizen Works, 2004). According to one study, these and similar scandals have cost American workers' $401 \mathrm{~K}$ plans over $\$ 175$ Billion, and have also resulted in the loss of over one millions jobs. (American Family Voices, 2003)

In response to the public outrage stemming from these crimes, Congressional investigators repeatedly and harshly criticized the Boards of Directors for allowing the abuses, fraud, misuse of funds and other ethical violations that ran rampant in the corporations they were ostensibly responsible to oversee (U.S. Senate, 2002).

In the wake of these scandals came an increasing outcry from both the public and large institutional investors, demanding greater corporate governance and increased Board accountability. CalPERS (The California Public Employees' Retirement System) is the United States' largest public pension fund and controls over $\$ 180$ Billion of investments, much of it in American corporate securities. (CalPERS, 2005.) CalPERS has a set of rules and guidelines for Boards to follow (Steiner \& Steiner, 2002). These best practices include establishing a board with a majority of independent members, ensuring that the independent members met regularly without the CEO present, and prohibiting Directors from also serving as consultants to the corporation. Clearly their point of view is that greater Board independence will bring positive outcomes, or at least protect the shareholders.

\section{The Sarbanes-Oxley Act And Its Effect On Corporate Governance}

The Sarbanes-Oxley Act of 2002 was passed by Congress on January 23, 2002 and signed into law by President George Bush on July 30, 2002. (Thompson \& Lange, 2003). The Act significantly changes requirements for publicly traded companies' Boards of Directors, as well as the Auditing and Accounting functions that those companies must follow. Specifically, the Act changed or strengthened three major roles of Boards of Directors. New standards for the audit committees of publicly traded companies require all of their members to be outside directors. Annual and quarterly financial reports must now be signed and certified by the chief executive officer and the chief financial officer of the issuer(either or both of whom might be Directors as well.) And the Act requires that every public corporation establish and publish a corporate code of ethics, or explain to shareholders why such a code does not exist. (Giroux, 2004). 


\section{Increased Attention To Diversity And Inclusion As Corporate Strategy}

For most of the Twentieth Century, Boards of Directors of American corporations were composed predominantly, if not exclusively, of white middle-aged males. (Miller \& Katz, 2002) Even after the Civil Rights and Equal Employment Opportunities Acts, board structure did not significantly vary. In the beginning of the 1990's this trend began to change. American corporations are now specifically attempting to increase the gender and ethnic diversity of their Boards, and are doing so not only for legal compliance but because they indicate a potential strategic advantage (Frankel \& Cole, 2004). This is another major change in Board composition and justifies a new look at its affect on financial performance. This updated look is described below.

\section{APPROACH}

This article will take a narrative, rather than meta-analytic approach in updating the Dalton work. There are two primary reasons for this. First, the 1998 article incorporated the results of 63 discrete research studies. A search of the relevant literature since 1998 simply did not yield a comparable enough number of new studies to support the full meta-analytic approach. Second, Dalton et al (1998) pointed out in their conclusion that their focus had been on Fortune 500 companies, and expressed some doubt as to how broadly their findings could be extended beyond that sample. Therefore, this article will consider research studies which were done post-1998, and will also review findings from direct primary study of published information regarding selected fortune 500 companies. Finally, the time constraints of this project simply do not allow for a full-blown meta-analysis as was performed in 1998.

The writer recognizes that this approach also has its drawbacks. It is not a purely quantitative method, as was the meta-analysis. As such, it cannot be predicted to apply beyond the sampling itself. At the same time, it should be borne in mind that the consequences of the Enron scandal, the Sarbanes-Oxley Act and the increasing presence of women and people of color on boards of directors is being evidenced most visibly at large publicly-held companies, which are the types of companies included in the Fortune 100 list. Lastly, because of the comparatively short period of time between the Dalton meta-analysis and the present, it seems reasonable to surmise that much of the information desired for this analysis may be only directly available, as it has not yet necessarily been gathered into published form.

\section{FINDINGS}

Seventeen research articles published between 1999 and 2004 were found and reviewed. Three criteria were applied to determine if they would be included in this update. First, they must examine results of U.S. corporations rather than international corporations. For example, a fairly significant body of research has been published regarding corporate governance in Asian companies (e.g. Leng, 2004, and Xu \& Wang, 1999). While this research is of interest, several of the post-1998 factors discussed above, such as the Sarbanes-Oxley Act, apply only, or at least predominantly, to American corporations. A second criterion was that the study be as close as reasonably possible to those works that were reviewed in the Dalton study. This meant they must contain quantitative research applied to determine the impact of Board structure on corporate financial performance. Finally, if the results of a study could be found summarized in another study, only the summary study itself was used. Based on these criteria, two of the more significant studies, in terms of their size and scope, were selected to be discussed in more detail. These studies were chosen for deeper discussion because they incorporated reviews of multiple other studies. In addition, we will also look at two follow-up articles written by two of the Dalton work authors themselves (Daily, Dalton \& Cannella, 2003 and Dalton, Daily, Certo \& Roengpitya, 2003).

\section{Bhagat and Black}

Bhagat and Black (2002) published what they described as "the first large-sample, long-horizon study of whether the degree of board independence correlates with various measures of the long-term performance of large American firms." (231). They first reviewed a number of existing studies, describing their own previous studies and dividing the research into two large groups. The first group studies the question of whether board independence may affect the board's performance of certain tasks, such as CEO selection. Here the authors found some benefits to independent boards for certain tasks, but not for others. The second group, which includes the 1998 Dalton studies, 
concentrates on whether board composition affects overall corporate performance. As in the Dalton work, Bhagat and Black found that "prior research does not support a clear correlation between board independence and firm performance." (236). In fact, they even suggesting that in certain instances, greater independence of the board could actually lead to worse corporate performance. (233)

The authors then report on their own study of nearly 1000 large American firms. They tracked both board composition and firm performance data from the late 1980's to the mid-1990's, correcting for entry and exit from the sample. Like Dalton and Daily, they incorporated several control variables, including board size, firm size, CEO ownership and others.

Once again, little support was found for a position that board composition impacts firm performance. The authors, possibly because they wrote the article in the post-Enron era, offer suggestions for experimenting with different board structures. They even suggest that boards may not be independent enough, and describe possible reconfigurations such as different methods of compensating and incentivizing board members. (266)

\section{Coles, McWilliams \& Sen}

Another study (Coles, McWilliams \& Sen, 2001) reviewed researchers' attempts to determine "how to design corporate governance mechanisms that will motivate managers to make choices for the firm that will improve performance." (24) The authors attempted to contribute to the body of knowledge by combining the variables of board composition, leadership structure, ownership structure, and CEO compensation for what they believed was the first time. They offered examples of outside director effectiveness in improving the firm's response to specific situations, including CEO turnover and positive market perception of the company's leadership structure. (27). Their sample included 144 firms and used Market Value Added and Economic Value Added as their performance measures. Like other researchers, they controlled for firm size and existence of significant block holders. But somewhat unique to other studies, they also considered industry performance as a control variable, positing that this could be a major influencer of a firm's results, quite independent of board structure or governance mechanisms. They tested seven hypotheses:

H1: Firms that separate CEO and Chair will have better performance than firms that join the two positions

H2: Firms with higher proportions of independent outsider Board members will have better performance than firms with a higher proportion of insiders on the board.

H3: Firms with higher proportion of stock ownership by Board members will have better performance than firms where Board members have lower ownership proportions.

H4: Firms whose CEO compensation plans are positively tied to firm value creation will have better performance than firms where CEO compensation is not so closely tied.

H5: Firm performance increases as the level of CEO stock ownership increases.

H6: Firm performance will also increase as the tenure of the CEO lengthens.

H7a: Firms whose governance structure lack organizational monitoring but emphasizes CEO incentives will perform better than firms whose structures lack organizational monitoring and do not emphasize such CEO incentive mechanisms.

H7b: Firms whose governance structure emphasizes organizational monitoring but lacks CEO incentives will perform better than firms whose structures lack organizational monitoring and do not emphasize such CEO incentive mechanisms.

This study produced conflicting results depending on which combinations of variables were considered, leading the authors to conclude that "long term value maximization need not, and probably will not, induce any significant relationships between Economic Value Added and variables representing firm ownership and governance structure." (48) 


\section{Updated Work By Dalton Study Authors}

In two separate but similar articles (Daily, Dalton \& Cannella, 2003 and Dalton et al, 2003) two of the authors of the 1998 Dalton study reiterated their position that the data provide no consistent support for positing a direct link between board structure and firm financial performance. They admitted that they raise more questions than they answer, and that possibly quantitative research would not provide the direct link that they and so many others have sought to show. This line of thought will be revisited in the conclusion of this article.

\section{Primary Research On Fortune Companies}

It is noteworthy that, although both the Bhajat and Black (2003) and the Coles, McWilliams and Sen (2001) pieces were published in the past five years, none of them included data from later than 1995. As discussed earlier, the collapse of Enron, Tyco, WorldCom and others, and the Sarbanes-Oxley Act of 2002, dramatically altered the regulatory landscape for American corporations. Few studies have yet been conducted, or at least published, comparing post-Sarbanes Board composition and financial performance. For this reason, a direct and more current look at several U.S. companies seemed in order.

Table 1 shows the top 30 of the 2003 Fortune 100 companies, including the proportion of outsider Directors on the Board. ("Out Pct") For this article, an outsider was defined as a person not employed by the Corporation in a non-Director capacity, whether currently or within the preceding three years.

Fortune 100 companies were chosen for three reasons. First, they are mostly publicly traded so more information is readily available regarding both their Board composition and financial performance. Secondly, they are already recognized as large and successful companies as measured by sales. This helps to moderate one of the major effects identified in the Dalton study, that of firm size. Thirdly, because their earnings growth has been relatively stable, it should be easier to isolate the effects of board composition as opposed to industry growth, for example.

As a measure of financial performance, this article tracks change in shareholder value ("Inc Value"), measured by adjusted percentage increase or decrease in share price from February 28, 2003 to February 28, 2005. This measure was chosen due to its availability for all publicly traded US companies, and its common-size attribute makes it an appropriate way to compare financial performance among companies of admittedly different size.

The "Div Rank" column lists the corporation's position, if any, in the DicversityInc.com Top 50 Companies for Diversity (Frankel \& Cole, 2004), which rates companies based on factors such as management demographics, CEO commitment, and supplier diversity.

All of the companies sampled had a significant majority of outside directors $-67 \%$ to $92 \%$ of each company's Directors were classified as outsiders. Furthermore, except for the one company with $67 \%$ outside directors, every corporation in the sample had at least $70 \%$ outside directors on its board.

Despite the strong preponderance of outside Directors, returns from the two-year period varied widely, from a low of negative $34 \%$ to a high of $130 \%$. The company with the highest return had $81 \%$ outside directors, while the company with the worst return had $82 \%$. This small sample, containing all heavily-outside dominated boards, produced vastly different financial results, again lending support to the thought that board structure itself does not impact firm performance.

The overall mean increase in value for the 29 companies (State Farm Insurance was not considered because it does not sell its stock publicly) was $46 \%$. The mean value increase for the 11 companies ranked in the Diversity Top 50 was $29 \%$, suggesting that diversity alone may not be tied to increased share value. 
Table 1: Top Thirty Fortune 100 Companies Ranked By Sales

\begin{tabular}{|c|c|c|c|}
\hline Company & Inc Value & Out Pct & Div Rank \\
\hline 1. Wal-Mart Stores Inc. & $9.1 \%$ & $71 \%$ & \\
\hline 2. Exxon Mobil Corp. & $95.5 \%$ & $80 \%$ & \\
\hline 3. General Motors Corp. & $16.5 \%$ & $79 \%$ & 40 \\
\hline 4. Ford Motor Co. & $61.8 \%$ & $81 \%$ & 3 \\
\hline 5. General Electric Co. & $53.8 \%$ & $75 \%$ & \\
\hline 6. ChevronTexaco Corp. & $119.1 \%$ & $86 \%$ & \\
\hline 7. ConocoPhillips & $130.3 \%$ & $81 \%$ & \\
\hline 8. Citigroup Inc. & $52.6 \%$ & $78 \%$ & 2 \\
\hline 9. International Business Machines Corp. & $20.6 \%$ & $86 \%$ & 5 \\
\hline 10. American International Group & $36.6 \%$ & $67 \%$ & \\
\hline 11. Hewlett-Packard Co. & $35.5 \%$ & $89 \%$ & 17 \\
\hline 12. Verizon Communications Inc. & $13.0 \%$ & $91 \%$ & 4 \\
\hline 13. The Home Depot Inc. & $73.6 \%$ & $92 \%$ & \\
\hline 14. Berkshire Hathaway Inc. & $-34.0 \%$ & $82 \%$ & \\
\hline 15. Altria Group Inc. & $90.4 \%$ & $91 \%$ & \\
\hline 16. McKesson Corp. & $42.3 \%$ & $90 \%$ & \\
\hline 17. Cardinal Health Inc. & $2.6 \%$ & $92 \%$ & \\
\hline \multicolumn{4}{|l|}{ 18. State Farm Insurance Cos. } \\
\hline 19. The Kroger Co. & $36.1 \%$ & $89 \%$ & \\
\hline 20. Fannie Mae & $-4.0 \%$ & $82 \%$ & 26 \\
\hline 21. The Boeing Co. & $106.9 \%$ & $91 \%$ & \\
\hline 22. AmerisourceBergen Corp. & $9.3 \%$ & $89 \%$ & \\
\hline 23. Target Corp. & $79.8 \%$ & $89 \%$ & \\
\hline 24. Bank of America Corp. & $54.4 \%$ & $78 \%$ & 23 \\
\hline 25. Pfizer Inc. & $-8.1 \%$ & $81 \%$ & \\
\hline 26. J.P. Morgan Chase \& Co. & $74.0 \%$ & $82 \%$ & 21 \\
\hline 27. Time Warner Inc. & $52.2 \%$ & $76 \%$ & 49 \\
\hline 28. Proctor \& Gamble Co. & $38.0 \%$ & $91 \%$ & 30 \\
\hline 29. Costco Wholesale Corp. & $54.1 \%$ & $86 \%$ & \\
\hline 30. Johnson \& Johnson & $29.8 \%$ & $76 \%$ & \\
\hline
\end{tabular}

\section{CONCLUSIONS}

The fact seems to remain that, as pointed out in the 1998 study, quantitative analysis will not demonstrate any clear correlation between Board Composition, $\mathrm{CEO} / \mathrm{Chair}$ duality and firm financial performance. However, the fact that something cannot be proved certainly doesn't mean that it isn't true. Part of the problem may in fact stem from the choice of method. Virtually all of the research reviewed in this area has been performed using the Analytical methodology, which Arbnor \& Bjerke (1997) describe as assuming that "the whole is equal to the sum of its parts; knowledge does not depend on individuals; parts are explained by verified judgments." (53)

It is possible that this choice of methodology is at least partially responsible for the continued inability to define a clear relationship between board structure and financial performance. Financial performance is affected by so many variables, including industry performance, economic factors, political changes, even climate changes in some cases, that it is a daunting task to isolate the effect of Board Composition itself. The Dalton study alludes to this but may not attach sufficient importance to it. So many other moderating factors take place that it may be impossible to define a direct connection with financial performance. For example, the Board composition of Company A may change from insider to outsider-dominated. This may be followed by a period of economic boom or bust which positively or negatively impacts the organization's financial results. It is impossible to separate the effects of the external environment from that of the change in board composition. Similarly, Company A and Company B may be the exact opposite of each other in terms of embracing an Insider or Outsider Board approach. But is everything else 
about these two companies identical? Obviously not. This, too, makes it extremely difficult to isolate the effect of this one factor.

There is also an important question of whether improved financial performance is even the primary goal of a specific Board structure. Or does the Board benefit the corporation more by focusing on maintaining and ensuring integrity and accuracy of business reporting and practices? The report of the Sixth International Conference on Corporate Governance and Board Leadership would indicate that group's opinion that the latter is true. Of the four major challenges listed as facing Corporate Directors in 2003, only one of them even mentioned improving corporate performance. The more important challenges centered around on rebuilding the reputation of corporations, and on reforming items such as board structure, CEO pay, and audit procedures. (Taylor, 2004)

Also, even if public and stockholder perception is that a company's financial reporting is accurate, that its managers are people of integrity, and that its actions and decisions are ethical, this may or may not translate to higher financial performance for the company. The evidence in this area is inconclusive. For example, Wal-Mart is the target of significant criticism from stockholder activists, union proponents, and progressives. However, its profits remain extremely healthy and it continues to grow. (Fortune, 2005) Philip Morris has paid millions of dollars in settlements and fines for promoting tobacco, yet they recorded operating income of over $\$ 6.5$ Billion in 2004, an increase of $4.5 \%$ over the prior year. (Philip Morris, 2005) AIG Insurance was the subject of a recent article that discussed why, in spite of them 'breaking all the rules' about board structure, investors continued to put their money in... and the company continued to hit high earnings (Byrne, 2002)

Does this mean that the public approves of cigarette smoking? Of predatory marketing or exploitative labor practices? Or an insider-dominated board of Directors? Not necessarily. It simply means that investors who choose these companies (owner/shareholders) might consider profitability and return on investment more important than some of these ethical or value issues, or at least consider the two issues separately. This would be very much in line with theories espoused by Milton Friedman whose famous proclamation that a corporation's only social responsibility is to make money (Friedman, 1970) is the basis for the school of Market Capitalism thought which bears his name. Friedman states that businesses should make money, period. He goes even further by stating that corporations have no right to contribute their shareholders' money to charitable causes, no matter how worthy. That is a decision, he says, for the shareholders to make with their personal funds.

The continual argument between Agency theory and Stewardship Theory may perhaps be considered more productively by looking at the problem through a different lens than that of the analytical method. The interaction and interrelationships between board and Managers (specifically CEO) is of paramount interest. Relationships and how they are defined by the parties involved lend themselves to a Systems approach more than an analytical one. The interaction among Directors and Managers, Directors and shareholders and Managers and shareholders creates a dynamic system which cannot be easily defined using purely quantitative measures. A case study approach may be much more effective. It is possible that by interviewing Directors, Managers and shareholders of various companies with different board structures, patterns of perception and relationships might emerge. Perhaps managers feel they should be compensated for maintaining and improving not only the short - term profits but also the long-term strategy of the company. Perhaps the board feels they should focus on monitoring and compliance rather than trying to set strategy, when most Board members can not work fulltime on their Board duties (O'Donoghue, 2004). Yet shareholders may believe that the Board should take a more active role in, for example, CEO selection.

Future research may prove more beneficial by focusing on the importance investors, Director and Managers place on "soft" topics such as these, rather than trying to definitively prove a relationship between Board structure and financial performance of the corporation. (Van den Berghe \& Levrau, 2004) These studies might be better done using qualitative techniques as some researchers (e.g. Leblanc, 2004) have suggested may be better suited to this task. 


\section{REFLECTIONS ON AUTHOR'S LEARNING}

This author began with a notion that a more definitive answer could be found by examining more and more studies. If there were inconsistent results, the assumption was that those inconsistencies might be removed by focusing on more current research, especially since the question of corporate governance and board structure has received so much attention in the intervening years.

It was rather surprising, then, to find no more clarity even in those current studies. It was not until that point that two ideas began to emerge in parallel. One was an idea which has become one of this author's main research paradigms: "Simply because something can't be statistically proven does not necessarily mean it does not exist." This led to the concluding remarks above, suggesting that more of a systems approach might be more useful. Possibly Board structure carries a more subtle impact on firm performance (Hillman \& Dalziel, 2003), by indirectly influencing decisions and values, but there are so many intervening variables that the effect cannot be easily seen.

The second thought was that some meta-analyses seem to rehash the same question over and over, regardless of achieving essentially the same result. This led back again to the thought that perhaps a different approach is needed. If the answer can't be found, no matter how many times we try the same technique, then perhaps a new technique is called for - maybe we're just not asking the right questions - or the right people - or asking them of the right people in the right way!

\section{REFERENCES}

1. Alsop, R. (2004) Corporate reputation: Anything but superficial. Journal of Business Strategy, 25(6). 21-29.

2. American Family Voices (2003) The Cost of Corporate Recklessness. Retrieved March 16, 2005 from http://www.americanfamilyvoices.org/pdf/cost.pdf.

3. Arbnor, I \& Bjerke, B.(1997) Methodology for Creating Business Knowledge. Thousand Oaks, CA: Sage.

4. Bhagat, S. \& Black, B. (2002) The non-correlation between board independence and long-term firm performance. Journal of Corporation Law, 27(2). 231-273.

5. Byrne, J. A. (2002, October 7) Great numbers, weak governance: Is AIG a special case? Business Week, 3802. p. 116

6. CalPERS (2005). About CalPERS. Retrieved March 12, 2005 from http://www.calpers.ca.gov/index.jsp?bc=/about/home.xml

7. Citizen Works (2004). The Cost of Corporate Recklessness. Retrieved March 1, 2005 from http://www.citizenworks.org/enron/corp-scandal.php

8. Coles, J., McWilliams, V., \& Sen, N. (2001). An examination of the relationship of governance mechanisms to performance. Journal of Management, 27. 23-50.

9. Corporate Governance(2005). Enhancing the return on capital through increased accountability. Retrieved March 20, 2005 from http://www.corpgov.net/index.htm.

10. Culpan, R. \& Trussel, J. (2005). Applying the Agency and Stakeholder Theories to the Enron Debacle: An Ethical Perspective. Business and Society Review, 110 (1) 59-76.

11. Daily, C., Dalton, D. \& Cannella, A. (2003). Corporate governance: Decades of dialogue and data. Academy of Management Review, 29 (3). 371-382.

12. Dalton, D., Daily, C., Certo, S. T. \& Roengpitya, R. (2003). Meta-analyses of financial performance and equity: Fusion or confusion. Academy of Management Journal, 46 (1). 13-26.

13. Dalton, D., Daily, C., Ellstrand, A. \& Johnson, J. (1998). Meta-analytic reviews of board composition, leadership structure, and financial performance. Strategic Management Journal, 19 (3). 269-290.

14. Frankel, B. \& Cole, Y. (2004). The DiversityInc 2004 Top 50 Companies for Diversity. Retrieved March 10, 2005 from http://www.diversityinc.com/members/6696.cfm.

15. Friedman, M., (1970, September 13). The social responsibility of business is to increase its profits. The New York Times Magazine, Retrieved March 1, 2005 from http://www.colorado.edu/ studentgroups/libertarians/issues/friedman-soc-resp-business.html

16. Giroux, G.(2004). Detecting Earnings Management. Hoboken: John Wiley \& Sons. 
17. Hillman, A. \& Dalziel, T.(2003). Boards of directors and firm performance: Integrating agency and resource dependence perspectives. Academy of Management Review, 28(3). 383-396.

18. Jensen, M. \& Meckling, W. (1976). Theory of the firm: Managerial behavior, agency costs and ownership structure. Journal of Financial Economics, 3. 305-350.

19. Leblanc, R.(2004). What's wrong with corporate governance: A note. Corporate Governance, 12(4). 436441.

20. Leng, A.(2004). The impact of corporate governance practices on firms' financial performance: Evidence from Malaysian companies. ASEAN Economic Bulletin, 21(3). 308-318.

21. Miller, F. \& Katz, J. (2002). The Inclusion Breakthrough: Unleashing the Real Power of Diversity. San Francisco: Berrett-Koehler.

22. Steiner, G. \& Steiner, J. (2003). Business, Government and Society: A Managerial Perspective. Boston: McGraw-Hill.

23. Thompson, J. \& Lange, G. (2003, Spring.) The Sarbanes-Oxley Act and the changing responsibilities of auditors. Review of Business, 24(2) 8-12.

24. United States Senate (2002, July 7). Senate Subcommittee Report Charges Enron Board of Directors with Contributing to Enron's Collapse. Retrieved March 12, 2005 from http://www.senate.gov/ gov affairs/070702psipress.htm

25. Xu, X. \& Wang, Y. (1999). Ownership structure an corporate governance in Chinese stock companies. China Economic Review, 10(1)

\section{NOTES}

